\title{
Local Community Empowerment Through Vocational Training in Tourism on Karimunjawa Islands : Poor- Poor Tourism Approach
}

\author{
Budi Setiawan ${ }^{1)}$ \\ ${ }^{1)}$ Doctoral Student at Gadjah Mada University, UGM \\ Departement of Economy \\ Muhammadiyah Purworejo University \\ e-mail : setiawanbudi75@gmail.com \\ M. Baiquni ${ }^{3)}$ \\ 3) Departement of Geoghraphy Development \\ Gadjah Mada University, UGM \\ e-mail : baiquni99@gmail.com
}

\author{
R. Rijanta ${ }^{2)}$ \\ 2) Departement of Geoghraphy Development \\ Gadjah Mada University, UGM \\ e-mail :masrijanta@yahoo.com
}

\begin{abstract}
This research analyzes the characteristics of the local community on Karimunjawa Island with a poverty rate of $32 \%$ of the total population. It is a qualitative research supported by a quantitative approach. The data are collected through in-depth interview and survey. The results of research show that the traditional farmers and fishermen that disperse from the island are categorized as extremely poor. The poverty they experience is that of earnings. On the other hand, Karimunjawa has the potential to be a place of popular resort or holiday destination. The local people are interested in participating in tourism related activities. This research recommends strategies for community empowerment as an effort to eliminate poverty and enhance the quality of human resources through a Pro-Poor Tourism (PPT) approach based on vocational training in tourism.
\end{abstract}

Key words - local community; poverty; small islands; vocational training in tourism.

\section{INTRODUCTION}

As the world's largest archipelagic nation, Indonesia has thousands of small islands with a number of endemic features of extremely typical and valuable diversity. Physically the small islands comprise small-sized land area which has implications for the life of the people in these regions. Rijanta (2005) [1] explains that these small islands, besides having abundant potential marine resources; are extremely vulnerable to the volatile condition in the ecosystem, the environment, as well as the sociocultural and political turbulence. They are subject to physical and social isolation and the slow-moving demographic dynamic and accelerating migration. The condition of the regions which consist of small islands with limitations in transportation makes it difficult for the inhabitants to gain access to decent living, which enables them to survive.
One of the major problems faced by the local communities on the small islands in poverty, which is issue for Indonesia as a maritime nation. The majority of the population that inhabit the small islands earn their livelihood in the sea and agriculture. Fishing and farming are two sectors in which the poor stand at a high employment figure (Standford, et al., 2013 [2]; Rashed, et al., 2011[3]; Dien, 2009 [4]). The typical characteristics of the small islands cause the farmers to encounter obstacles in their process of production. Limitations in the availability of land, the supply of water, access to the market and also the threat of climate change make it hard the farming communities to develop. Fishing is a significant and important choice of occupation to increase their earnings and maintain food security of the poor households with inadequate farmlands (Martin, et al., 2013) [5]. On the other hand, the fishermen are under the increasing threat of climate change and the environment such as increased sea level, acidification of the sea, and the rise of the surface of the seawater (Cochrane et al., 2009[6]; Johnson and Welch, 2010 [7]). The fishermen are also affected by economic policies, privatization of public facilities, deregulation of various economic activities and the market, as well as progressive liberalization of foreign trade (UNEP, 2002) [8].

The small islands with their fragile ecological condition, traditional socioeconomic structure, limited resources and undeveloped infrastructure (Lewis \& Roberts, 2010) [9] require alternatives of economic development, one of which is tourism. However, tourism can be useful if it is devised and integrated into the local system (Wilkinson, 1989) [10] especially when the promotion and development of tourism are done in 
partnership involving the government, NGO (Non Governmental Organization) and the local community.

This article begins with description of the characteristics of poverty among the local people on the island of Karimunjawa before analyzing the key issues concerning empowerment of the local people and the development of tourism on the island. This article is intended to address the issues of social sustainability which should be prioritized of tourism is used as a means of alleviating poverty of the local people on the small islands.

\section{METHODOLOGY}

The research was conducted in two villages on the island of Karimunjawa, i.e. Karimunjawa village and Kemujan village. The research design was a qualitative approach and the technique of data collection was in-depth interview.

\section{RESULTS AND DISCUSSION}

\section{A. Poverty and Tourism on Karimunjawa Island}

The subdistrict of Karimunjawa administratively consists of the villages of Karimunjawa, Kemujon, Parang, and Nyamuk. All the villages in the subdistrict are typologically coastal at an altitude of under 500 meters. The center of administration of Karimunjawa subdistrict is located on Karimunjawa Island, 81 miles from Kartini seaport in Jepara, which can be reached by boarding Bahari Express Sailing Ship, which takes about two hours or less than four hours by speedboat.

In 2013 Karimunjawa Sub district had a population of 9,016 consisting of 4,547 men and 4,469 women. It was a subdistrict with the most sparsely populated in Jepara Regency (0.78\%), which comprised 2,621 households so that on average a household in Karimunjawa Sub district consisted of 2-4 members. Karimunjawa Village was the most densely populated, i.e. 4,557 or $50.54 \%$ of the population in the subdistrict, whereasNyamuk village was the most sparsely populated, i.e. 551 or $6.11 \%$.

The problem is, according to a report by the Central Agency of Statistics (CAS) in Jepara, in 2014 the poverty rate in Karimunjawa Subdistrict is high, i.e. $60.2 \%$ poor households, which are scattered in four villages with the highest percentage in Karimunjawa village and Kemujan village (Table 1). The poor and extremely poor households in Karimunjawa Subdistrict are 1,803 in number with the total members of 7,212 (assuming four members per household). Based on observation in the field, the poverty on this island is caused by the low earnings of the farmers and fishermen, the biggest communities on Karimunjawa Island. These earnings are due to their in ability to maximize the access to the local potentialities. It is increasingly difficult for the traditional fishermen in Karimunjawa to have a maximum catch of fish and they fail to compete with other fishermen who have modern equipment. Their catches began diminish even more when large ships came to operate there. These ships are furnished with cold storage, sophisticated tools for catching fish, a fish finder, a radio for communication, and a magnetic compass. The fish caught by the traditional fishermen are merely sufficient to meet their basic needs, especially food. These subsistent farmers are not capable of introducing innovations to increase productivity and maximize land management of unirrigated and wet rice fields. Not much technology has been developed in the agricultural and animal husbandry sectors in Karimunjawa. Limitations in the availability of land and water as well as the dynamic climate change make it hard for the agricultural sector to develop. As a matter of fact, it is very difficult to distinguish between the communities of fishermen and farmers and classify them into two groups in terms of means of livelihood because in reality many of them are enganged in both spheres. At certain times they cultivate the fields, but at other times they also go fishing or manage inland fisheries.

The high poverty rate in Karimunjawa Subdistrict runs parallel with the data on the low levels of education. Most of the people there are Primary School leavers (47.98\%), and in fact there is a considerable number of those who did not finish Primary School education, i.e. $32.67 \%$. Considering the high percentage of the productive age group, the quality of human resources in the subdistrict is arguably low.

Table 1. The total of Households according to welfare status

\begin{tabular}{|c|c|c|c|c|c|c|}
\hline Villa-ges & $\begin{array}{c}\text { Pre- } \\
\text { welf } \\
\text { are }\end{array}$ & $\begin{array}{c}\text { Welfa } \\
\text { re } \\
\text { I }\end{array}$ & $\begin{array}{c}\text { Welfa } \\
\text { re } \\
\text { II }\end{array}$ & $\begin{array}{c}\text { Welfa } \\
\text { re } \\
\text { III }\end{array}$ & $\begin{array}{c}\text { Welfa } \\
\text { re } \\
\text { Plus }\end{array}$ & $\begin{array}{c}\text { Tot } \\
\text { al }\end{array}$ \\
\hline $\begin{array}{c}\text { Karimunj } \\
\text { awa }\end{array}$ & 481 & 400 & 251 & 218 & 156 & $\begin{array}{c}1,5 \\
06\end{array}$ \\
\hline Kemujan & 271 & 309 & 197 & 105 & 53 & $\begin{array}{c}93 \\
5\end{array}$ \\
\hline Parang & 125 & 102 & 48 & 27 & 23 & $\begin{array}{c}32 \\
5\end{array}$ \\
\hline Nyamuk & 60 & 55 & 32 & 17 & 13 & $\begin{array}{c}17 \\
7\end{array}$ \\
\hline Total & 937 & 866 & 528 & 367 & 245 & $\begin{array}{c}2,9 \\
43\end{array}$ \\
\hline
\end{tabular}

Source: Karimunjawa Subdistrict in Figures, CAS, 2014

Most of the people in Karimunjawa work in the informal sector, i.e. $88.56 \%$ with the higher percentage as fishermen $(59.53 \%)$, and as farmers $(19.32 \%)$ whereas others work as farm laborers, artisans/craftmen, shopkeepers/tradesmen, breeders and mechanics.

One of the potential spheres for economic development on the island is tourism, which is the largest industry in the world and has been an integral component of the strategy for economic development in various countries. Tourism has the potential for yielding foreign exchange, drawing international investments, increasing tax revenues, and creating new opportunities for employment. Visits by domestic and foreign tourists to Karimunjawa Island have significantly increased since 2010. In 2014 there were 8,699 foreign visitors to the island, a sharp increase compared with those in 2012 and 2013 , i.e. only 5,005 and 5,372 respectively (Tourism 
Information Center of Jepara, 2014) [11]. The tourism sector has become increasingly attractive to the people of Karimunjawa so that many of them have switched their interest to this sector as an additional means of livelihood. The kinds of economic activity that they do are, among others, making souvenirs, renting boats, guiding tourists, and renting out modest homestay accommodation but these are casual work, not their main occupations depending on the number of visitors or holiday-makers and the climatic conditions in Karimunjawa.

\section{B. Pro-Poor Tourism Approach in Local Community} Empowerment

The term "Pro-Poor Tourism" (PPT) was introduced in 1999 and implemented in Britain for economic development by putting tourism as a sector that could contribute to poverty alleviation. PPT is not aimed at expanding the scale of tourism but opening up opportunities for the poor people in tourism at all levels and scales of operation (Ashley et. al., 2001) [12].

The strategies of PPT development are 1) to improve economic benefits; to open up business opportunities for the poor, and to raise the people's collective incomes (payments), and 2) to improve non-economic benefits, and build up capabilities, set up training and practice; to reduce the environmental impact of tourism on the poor, to cope with the sociocultural effect of tourism. The PPT approach is very interesting in terms of analysis on means of livelihood (Ashley, 2000 [13] and Ashley, et.al, 2001). This analysis is important if tourism will be used to contribute to the welfare of the poor. In order to maximize the contribution of households and to avoid the poor households' dependence tourism can be used to diversify the people's means of livelihood.

In the context of tourism development, local participation is important, not only to fill the demand for manpower but also to provide services that encourage more visitors to come through the local people's attitude and lifestyle. Tourism development depends not only on natural resources and the attraction of promotion campaigns but also on the willingness of locals to welcome tourists and give them satisfactory services. The locals' preparedness is a moral support for the tourism sector and it directly reflects their readiness to participate in the tourism industry.

\section{Tourism Vocational Training for Local Community Empowerment}

This research was carried out in the areas of the poor local community in Karimunjawa. Ten heads of households were invited for in-depth interview to elicit information on their willingness to alleviate poverty in their community through activities in tourism. The results of research indicate that poor households are willing to be involved in the tourism sector provided that they are given employment opportunities and earn enough to build their houses, to enhance their self-esteem, to maintain their health and ensure an increase in their income.
One of the efforts to eliminate poverty on the island is empowerment of the local community through vocational training. Under the existing conditions of the majority of the people, i.e. poverty and low levels of education, one model of empowerment is vocational training oriented to the development of the informal sector, particularly tourism, which is at present a thriving industry in Karimunjawa.

The vocational training is only one aspect in the endeavour to improve the quality of human resources and to create job opportunities. This training should be able to develop the relevant skills needed for a supply of manpower and the growth of employment opportunities for new enterprises. A number of important aspects in the development of vocational education and training are as follows: 1) it should be able to fulfill the need for employment in the informal sector; 2) it should be able to empower people at the productive age with access to the labour market and involve them in the productive economy of tourism; 3) it should include all parties concerned in an effort to establish a link between vocational training and market demand and the business world; 4) the mechanism for the vocational training should be designed in a sustainable way and adjusted to a situation as well as the commitment and responsibility of the stakeholders; 5) it should form part of a sustainable development strategy at regional, national, and international levels.

The most important goal of vocational training for the elimination of poverty is to empower the local community not only with basic knowledge and skills but also with a real sense of ideological commitment imbued with motivation and zeal to combat poverty.

\section{CONCLUSION}

The PPT approach shows that there is a simple winwin scenario for the growth of tourism, economic development, and poverty alleviation. This article has attempted to reflect the significance of the PPT concept if it can be applied to empower the local community. One of the main concerns about tourism in a small island is the fact that there is environmental and economic vulnerability and indifference to the importance of social sustainability, particularly the problem of poverty.

Poverty that is prevalent in Karimunjawa is poverty in terms of meagre earnings due to the inability of the people in managing and maximizing the potential of the local resources. Other factors that cause poverty are interrelated such as insufficient availability of land both in quantity and quality, limited financial capital, inadequate access to technology and, most importantly, the low quality of human resources.

The strategies adopted to eliminate poverty in Karimunjawa should be integrated, comprehensive, and sustainable. One strategy is the development of human resources through vocational training for tourism, which can be instituted in a Community Learning Center often called Pusat Kegiatan Belajar Masyarakat (Center for Learning Activity). One important aspect in the strategy to 
empower the local community is to equip them not only or with basic knowledge and skills but with a sense of ideological commitment so that they are strongly motivated and enthusiastic to fight against poverty.

\section{RECOMMENDATIONS}

The government should undertake and implement the program of local community development in small islands. The strategy to empower the local community through vocational training can be adopted in small islands that have the potential for tourism. Facilities for the vocational training should be made available by the government, and all parties concerned should be remunerated. The government can give an opportunity to non-governmental organizations to be involved in this program, and encourage corporations through Corporate Social Responsibility (CSR) to take part in the provision of proper funding. In order to ensure the smooth implementation of the program, there is a need for routine evaluation to identify its strengths and weaknesses.

\section{REFERENCES}

[1] Rijanta, R. 2005. Insularitas dan Keterbelakangan Ekonomi Wilayah menuju Model Konseptual Perkembangan Wilayah PulauPulau Kecil di Indonesia. Majalah Geografi Indonesia. Yogyakarta

[2] Stanford, R.J., Wiryawan, B., Bengen, D.G., Febriamansyah, R. Haluan, J., 2013. Exploring fisheries dependency and its relationship to poverty, A case study of West Sumatra, Indonesia. Ocean. Coast. Manag. 84, 140e152.

[3] Rashed-Un-Nabi, M., Hoque, M.A., Rahman, R.A., Mustafa, S. Kader, M.A., 2011. Poverty profiling of the estuarine set Bag Net fishermen community in Bangladesh. Res. World Econ. 2 (2), 2e20.

[4] Dien, V.V., 2009. Poverty measurement, an application for smallscale fisheries in Bich Dam Island, Vietnam. Master Thesis. University of Tromso, Norway \& Nha Trang University, Vietnam.

[5] Martin, S.M., Lorenzen, K. \& Bunnefeld, N., 2013. Fishing Farmers: Fishing, Livelihood Diversification and Poverty in Rural Laos. Human Ecology, 41(5), pp.737-747. Available at: http://link.springer.com/10.1007/s10745-013-9567-y.

[6] Cochrane, K., De Young, C. \& Soto, D. (eds), 2009. Climate change implications for fisheries and aquaculture, Rome, Italy: The Food and Agriculture Organization of The United Nations (FAO) http://www.fao.org/fileadmin/user upload/newsroom/docs/FTP53 $0 . p d f$

[7] Johnson, J.E. \& Welch, D.J., 2009. Marine Fisheries Management in a Changing Climate: A Review of Vulnerability and Future Fisheries Science, 18(1), pp.106-124. DOI: 10.1080/10641260903434557

[8] UNEP, 2002. Integrated Assessment of Trade Liberalization and Trade-Related Policies : A Country Study on the Fisheries Sector in Argentina, New York, USA: UNEP.

[9] Lewis-cameron, A. \& Roberts, S., 2010. Small Island Developing States: Issues and Prospects. In A. Lewis-cameron \& S. Roberts, eds. Marketing Island Destinations: Concepts and Cases. Burlington: Elseiver/Butterworth-Heinemann, pp. 1-8.

[10] Wilkinson, Paul, 1989. Strategies for Tourism in the Island Microstates. Annals of Tourism Research 16 (1): 153-177. doi:10.1016/0160-7383(89)90065-0.

[11] Tourism Information Center Jepara, 2014. Statistik 2014 | TIC Jepara Your Gateway to Jepara Tourism, Jepara, Jawa Tengah, Indonesia. Available at: http://ticjepara.com/?p=5138.

[12] Ashley, C., Roe, D., \& Goodwin, H. (April 2001). Pro-poor tourism strategies: Making tourism work for the poor - A review of experience. Pro-Poor Tourism Report No. 1. ODI/IIED/CRT. Nottingham: The Russell Press. https://www.odi.org/sites/odi.org.uk/files/odi-assets/publicationsopinion-files/3246.pdf
[13] Ashley, C. 2000. The impacts of tourism on rural livelihoods: Namibia's experience. Working Paper 128. Sustainable Livilehood Series. Overseas Development Institute, London, UK. 